\title{
PENINGKATAN PERAN CIVITAS PERGURUAN TINGGI DALAM UPAYA TANGGAP BENCANA NASIONAL MELALUI EDUKASI DAN PENCEGAHAN PENYEBARAN WABAH PADA MASA PANDEMI COVID 19 DI KOTA KENDARI
}

${ }^{1}$ Andi Noor Kholidha Syarifin, ${ }^{2}$ Waode Sitti Asfiah Udu, ${ }^{3}$ Rahmawati

1-3 Jurusan Kedokteran, FK UHO, aan.chemist.06@gmail.com

Jl. HEA Mokodompit, Kampus Bumi Tridharma Anduonohu, Kendari 93232

\section{RINGKASAN}

COVID 19 pertama dilaporkan di Indonesia sejak Maret 2020 dan sampai dengan September 2020 jumlah kasus semakin meningkat dengan tingkat mortalitas sebesar 4,11\%. Pemerintah telah menyatakan status penyakit ini menjadi Bencana Nasional Darurat dan menghimbau masyarakat untuk melakukan langkah-langkah pencegahan seperti Pelaksanaan Hidup Bersih dan Sehat, sering mencuci tangan, menggunakan masker, dan melakukan physical distancing. Upaya pencegahan sudah secara massive dilakukan, namun jumlah pasien yang terkonfirmasi COVID 19 dan korban meninggal dunia masih terus bertambah. Kota Kendari merupakan salah satu daerah dengan jumlah kasus positif terbanyak di Sulawesi Tenggara. Dalam upaya pencegahan dan pengendalian wabah COVID 19, kegiatan pengabdian kepada masyarakat oleh Tim dosen dari Fakultas Kedokteran Universitas Halu Oleo, bersama mahasiswa dan pihak pemerintah daerah, merupakan salah satu perwujudan nyata yang selaras dengan program pemerintah melalui edukasi dan pencegahan penyebaran wabah pada masa pandemic covid 19 di Kota Kendari. Kegiatan pengabdian ini meliputi: edukasi dalam penanganan dan pencegahan COVID 19, pemberian dan edukasi penggunaan masker kain bagi masyarakat, pembuatan hand sanitizer, pembuatan tempat mencuci tangan, serta pengembangan Usaha Kecil Mikro dan menengah (UMKM) dalam pembuatan alat pelindung diri (APD). Kegiatan ini dilaksanakan di empat kecamatan di Kota Kendari, yaitu Kecamatan Kadia, Kendari Barat, Kendari, dan Nambo. Metode pelaksanaan kegiatan dilakukan secara daring maupun luring. Hasil yang dicapai dari pengabdian ini menunjukan meningkatnya pengetahuan dan pemahaman serta kesadaran masyarakat terhadap upaya pencegahan COVID 19; terdistribusinya APD masker, hand sanitizer, dan tempat cuci tangan; serta pemberdayaan pengembangan UMKM yang terdampak covid 19 melalui program pembuatan masker APD di empat kecamatan di Kota Kendari.

Kata kunci: pengabdian masyarakat; civitas perguruan tinggi; pencegahan; COVID-19.

\section{A. Analisis Situasi}

Kasus pneumonia misterius pertama kali dilaporkan pada Desember 20219 yang bermula ditemukan di Wuhan, Provinsi Hubei, China (Rothan, 2020). Sejak kasus pertama di Wuhan, terjadi peningkatan kasus COVID-19 di China setiap hari dan 
memuncak diantara akhir Januari hingga awal Februari 2020 (Wu and McGoogan, 2020). Tanggal 30 Januari 2020, telah terdapat 7.736 kasus terkonfirmasi COVID-19 di China, dan 86 kasus lain dilaporkan dari berbagai negara seperti Taiwan, Thailand, Vietnam, Malaysia, Nepal, Sri Lanka, Kamboja, Jepang, Singapura, Arab Saudi, Korea Selatan, Filipina, India, Australia, Kanada, Finlandia, Prancis, dan Jerman (WHO, 2020). Penyakit coronavirus disease 2019 (COVID 19) yang disebabkan oleh Severe Acute Respiratory Syndrome Coronavirus-2 (SARS-CoV-2) (WHO, 2020). Coronavirus adalah zoonosis atau virus yang ditularkan antara hewan dan manusia. Virus ini dapat ditularkan dari manusia ke manusia dan telah menyebar secara luas di China dan lebih dari 190 negara dan teritori lainnya (WHO, 2020). Penyebaran penyakit ini telah memberikan dampak luas secara sosial dan ekonomi. Sejak 12 Maret COVID-19 telah dinyatakan sebagai pandemi dunia oleh WHO (WHO, 2020).

COVID 19 pertama dilaporkan di Indonesia pada tanggal 2 Maret 2020 sejumlah dua kasus. Data 31 Maret 2020 menunjukkan kasus yang terkonfirmasi berjumlah 1.528 kasus dan 136 kasus kematian (Susilo, 2020). Sampai dengan 8 September 2020 menunjukkan kasus terkonfirmasi sebanyak 200.035 kasus dan 8230 kasus kematian dengan tingkat mortalitas sebesar 4,11\%. Kota Kendari merupakan salah satu kota dengan kasus konfirmasi COVID 19 terbanyak di Sulawesi Tenggara (https://covid19.go.id, 2020).

Presiden Republik Indonesia telah menyatakan status penyakit ini menjadi Bencana Nasional Darurat pada tanggal 13 April 2020. Presiden juga telah mengeluarkan Keputusan Presiden No. 7 Tahun 2020 tentang Gugus Tugas Percepatan Penanganan Corona yang diketuai oleh Kepala Badan Nasional Penanggulangan Bencana (BNPB). Gugus Tugas ini bertujuan untuk meningkatkan ketahanan nasional di bidang kesehatan; mempercepat penanganan COVID 19 melalui sinergi antar kementerian/ lembaga dan pemerintah daerah; meningkatkan antisipasi perkembangan eskalasi penyebaran COVID19; meningkatkan sinergi pengambilan kebijakan operasional; dan meningkatkan kesiapan dan kemampuan dalam mencegah, mendeteksi, dan merespons terhadap COVID 19. Selain itu, Menteri 
Pendidikan dan Kebudayaan juga telah mengeluarkan Surat Edaran No. 3 tahun 2020 mengenai Pencegahan Corona Virus Disease (COVID 19) pada satuan Pendidikan (www.kemdikbud.go.id, 2020).

Pemerintah menghimbau masyarakat untuk melakukan langkah-langkah pencegahan seperti Pelaksanaan Hidup Bersih dan Sehat, sering mencuci tangan, menggunakan masker, dan melakukan physical distancing.Upaya pencegahan sudah secara massive dilakukan oleh pemerintah, namun jumlah pasien dan korban juga masih belum bisa diturunkan secara signifikan. Masih banyak masyarakat yang belum secara sadar melaksanakan himbauan pemerintah. Selain itu, jumlah APD untuk tenaga kesehatan dan masyarakat juga dianggap masih belum memadai.

Dalam upaya pencegahan dan pengendalian wabah COVID 19, kegiatan pengabdian kepada masyarakat yang dilakukan oleh Tim dosen dari Fakultas Kedokteran Universitas Halu Oleo, bersama mahasiswa dan pihak pemerintah daerah, merupakan salah satu perwujudan nyata dari apa yang diarahkan oleh pemerintah saat ini.

Kegiatan ini dilaksanakan di Kota Kendari, mengingat Kota Kendari merupakan salah satu daerah dengan jumlah kasus positif terbanyak di Sulawesi Tenggara dan urutan kedua dengan jumlah ODP setelah kabupaten Muna. Data Terbaru menyebutkan, Per 15 April 2020, jumlah kasus positif di Kota Kendari sebanyak 19 orang. Dari 19 orang tersebut 1 orang dinyatakan sembuh dan 1 orang meninggal, serta 17 orang lainnya masih dalam proses isolasi dan menjalani perawatan di rumah sakit. Selain itu, update data orang dalam pemantauan (ODP) sebanyak 134 orang. Kemudian yang dinyatakan sembuh 98 orang dan 36 orang lainnya masih dalam pemantauan. Sementara kasus pasien dalam pemantauan (PDP) total 43 orang. Oleh karena itu, kegiatan ini dianggap penting untuk dilaksanakan untuk membantu memutuskan mata rantai penyebaran wabah covid-19 di Kota Kendari. 


\section{B. Metode Pelaksanaan}

Kegiatan pengabdian ini dilaksanakan pada Bulan Juli sampai dengan September 2020. Sasaran dalam kegiatan ini adalah warga masyarakat yang terdampak langsung maupun yang belum terdampak untuk mencegah perluasan dari pandemi Covid- 19 di empat kecamatan di Kota Kendari yaitu Kecamatan Kadia, Kendari Barat, Kendari, dan Nambo.

\section{a. Program Utama}

1. Melakukan Edukasi dalam penanganan dan pencegahan COVID 19: dengan cara memberikan edukasi secara langsung di masyarakat dengan menerapkan protokol kesehatan yang ketat di Kecamatan Kadia, Kendari, Kendari Barat dan Nambo serta secara online dengan memanfaatkan fasilitas media sosial di instagram dan youtube.

2. Melakukan Pemberian dan edukasi penggunaan masker kain bagi masyarakat dalam penanganan COVID 19 dengan membagikan masker kain secara merata kepada masyarakat terutama ekonomi menengah kebawah dan memberikan edukasi cara pemakaian masker yang benar dengan cara edukasi langsung di Kecamatan Kendari, Kendari Barat, dan Nambo.

3. Melakukan pembuatan hand sanitizer dan membagikannya kepada masyarakat dalam penanganan COVID 19 secara merata kepada masyarakat di Kecamatan Kadia, Kendari, Kendari Barat dan Nambo.

4. Melakukan pembuatan 15 titik tempat cuci tangan dalam penanganan COVID 19. Menyediakan barang logistik wadah cuci tangan untuk dibagikan atau di tempatkan di tempat-tempat umum seperti kantor kecamatan, masjid, rumah sakit, dan pondok pesantren.

5. Melakukan kerjasama dengan UMKM dalam pembuatan APD penanganan COVID 19 dengan bekerja sama dengan 4 UMKM yang berada di tiap Kecamatan yaitu Kecamatan Kendari, Kendari Barat, Kadia dan Nambo. Selanjutnya masker dibagikan ke masyarakat setempat. 
b. Program Tambahan

1. Melakukan pemasangan Baliho mengenai langkah langkah pencegahan Covid19 di tiap Kecamatan yaitu Kecamatan Kendari, Kendari Barat, Kadia dan Nambo agar masyarakat setempat dapat dengan mudah memperoleh informasi mengenai pencegahan Covid-19 sehingga dapat menerapkan protokol kesehatan saat new normal

2. Melakukan penyiaran melalui Radio RRI Pro 2 Kendari dengan tema Keselamatan dan Kesehatan Anak Saat Sekolah Pada Masa Pandemi Covid-19 sehingga masyarakat dapat mengetahui dan membimbing anak-anak untuk tetap menerapkan protokol kesehatan saat sedang bersekolah.

3. Melakukan pemasangan poster edukasi mengenai langkah-langkah pencegahan covid 19, etika batuk, cara memakai dan mencuci masker kain dengan tepat, 6 langkah cuci tangan, dan asupan nutrisi selama masa pandemi Covid-19 di tiap 4 kecamatan yaitu Kecamatan Kendari, Kendari Barat, Kadia dan Nambo.

4. Melakukan pembuatan video edukasi mengenai (etika batuk, cara memakai dan mencuci masker kain dengan tepat, 6 langkah cuci tangan, cara membuat hand sanitizer) dan mempublikasikan video tersebut melalui media 141ocial yakni instagram dan you tube

\section{Hasil dan Pembahasan}

Secara umum hasil dan luaran yang dicapai dalam kegiatan pengabdian ini dapat dideskripsikan sebagai berikut :

\section{a. Program Utama}

Program kerja yang telah dilaksanakan yaitu :

\section{Edukasi Pencegahan dan Penanganan Covid-19}

Dalam hal ini, edukasi kepada masyarakat dilakukan secara langsung di Kelurahan Anaiwoi Kecamatan Kadia dengan jumlah peserta terbatas serta menerapkan protokol kesehatan yang ketat. Pada penyuluhan ini edukasi yang 
diberikan kepada masyarakat berupa cara mencegah penularan penyakit Covid-19, seperti edukasi penggunaan masker, tata cara mencuci tangan serta penggunaan handanitizer. Pada penyuluhan ini, juga dibagikan Alat Pelindung Diri siap pakai berupa Masker dan Handsanitizer.

Untuk Kecamatan Kendari, Kendari Barat dan Nambo, edukasi kepada masyarakat dilakukan via daring melalui Whatsapp Group dengan mengundang masyarakat Kecamatan Kendari, Kendari Barat, Dan Nambo ke Whatsapp Group yang telah dibuat. Materi yang diberikan pada edukasi secara daring terdiri dari 3 yaitu Pencegahan Covid-19, Penggunaan Masker dan Langkah-langkah Cuci Tangan, dan Asupan Nutrisi Selama Pandemi Covid-19. Dalam edukasi via daring ini, digunakan media poster dan video agar lebih mudah dipahami oleh masyarakat. Edukasi online ini dilakukan karena dilaksanakan secara bersamaan di 3 kecamatan sehingga mengurangi risiko penularan Covid-19 yang jika dilakukan secara offline gabungan 3 kecamatan maka risiko penularan akan menjadi sangat tinggi.

\section{Pemasangan Tempat Cuci Tangan sebagai Langkah Penanganan}

\section{Covid-19}

Menyediakan wadah cuci tangan beserta sabun antiseptic agar masyarakat dapat menerapkan perilaku hidup sehat dalam pencegahan COVID-19. Pemasangan tempat cuci tangan portable di 15 titik lokasi yang telah kami tentukan berdasarkan hasil survey sebelumnya. Pemasangan dilakukan ditempat-tempat umum yang berpotensi dikunjungi oleh banyak orang, yaitu fasilitas pelayanan kesehatan seperti RS Dr. Ismoyo, RS Bhayangkara, RS Santa Anna, dan Puskesmas Nambo. Pemasangan tempat cuci tangan juga dilakukan di kantor Kelurahan (Kelurahan Kandai dan Kelurahan Anaiwoi) dan kantor Kecamatan (Kecamatan Kendari, Kecamatan Kendari Barat dan Kecamatan Nambo).Selain itu, Pemasangan juga kami lakukan di fasilitas pendidikan seperti di Pondok Pesantren Hidayatullah dan 
Pondok Pesantren Wushulul Fawwas dengan harapan agar para santri dapat menerapkan protokol kesehatan dalam pencegahan COVID-19.

\section{Pembuatan dan Pendistribusian Handsanitizer}

Pembagian Handsanitizer Kepada 4 Kecamatan yaitu Kecamatan Kendari, Kecamatan Kendari Barat, Kecamatan Nambo dan Kecamatan Kadia dengan target 75 Handsanitizer dengan volume $100 \mathrm{ml}$ per botol dan 100 botol dengan volume $65 \mathrm{~mL}$. Pemberian handsantizer kepada pihak kecamatan bertujuan agar pihak kecamatan dapat membagikan kepada masyarakat sehingga masyarakat dapat bekerja dengan aman dengan mengurangi risiko terpapar virus corona.

\section{Pengembangan UMKM Dalam Pembuatan APD Penanganan Covid-} 19

Pengembangan UMKM ditujukan kepada penjahit-penjahit seruni yang berada di Kendari khususnya di Kecamatan Kadia, Kendari Barat, Kendari dan Nambo yang memproduksi masker kain. Dampak dari pandemic Covid-19 membuat UMKM banyak mengalami kesulitan terutama dalam mendapatkan bahan baku, produksi dan arus kas. Distribusi APD masker kain dengan memperdayakan UMKM dengan menggunakan 240 pcs masker kain yang diproduksi oleh UMKM penjahit Seruni sebagai salah satu pengembangan UMKM di masa pandemic Covid-19.

\section{Pembagian Atau Pendistribusian Masker Kain Kepada Masyarakat.}

Masker kain yang telah di diproduksi dari UMKM, dibagikan secara gratis kepada masyarakat terutama kepada masyarakat yang memiliki usia rentan terkena virus Corona, kepada ibu-ibu dan anak muda yang suka berkumpul. Adapun penyaluran masker kain secara simbolis di lakukan di empat kecamatan yang telah di tentukan yaitu kecamatan Kadia, Kecamatan 
Kendari Barat, Kecamatan Kendari dan Kecamatan Nambo yang meruapakan kriteria lokasi rawan terjadi proses penularan Covid-19.

\section{b. Program Tambahan}

1. Pemasangan baliho edukasi pencegahan Covid-19 di Kecamatan Kendari, Kendari Barat, Kadia dan Nambo.

Pemasangan baliho di 4 kecamatan dimulai dengan tahap survei untuk tempat pemasangan baliho di tempat tempat umum yang merupakan tempat keramaian kemudian dilanjutkan dengan pemasangan baliho edukasi.

\section{Pembuatan Poster dan Video Edukasi}

Pembuatan poster edukasi terdapat 5 judul yaitu : (1) Etika Batuk/Pilek; (2) Lindungi Diri dan Keluarga dari Covid-19 dengan Berperilaku BIJAK; (3) Langkah-langkah Cuci Tangan; (4) Ingin Imunitas Tubuh Kuat? PAHAMI Asupan Nutrisi Tubuh Anda; (5) Ayo!!! Cegah Covid dengan WASPADA. Untuk pembuatan Video Edukasi terdapat 2 judul yaitu : (1) Langkah-langkah Cuci Tangan; (2) Etika Batuk. I

Poster edukasi dipublikasi melalui Akun Instagram dan Whatsapp Group Edukasi Kec.Kendari, Kendari Barat dan Nambo. Sedangkan Video edukasi dipublikasi melalui Akun Youtube dan Whatsapp Group Edukasi Kec.Kendari, Kendari Barat dan Nambo. Pemasangan Poster edukasi dilakukan agar saat masyarakat keluar rumah tetap dapat memperhatikan edukasi pencegahan Covid-19.

\section{Edukasi Covid-19 melalui RRI Kendari}

Edukasi melalui RRI Kendari ini merupakan kegiatan edukasi berdialog bersama RRI dengan Tema "Keselamatan dan Kesehatan Anak Saat Sekolah pada Masa Pandemi Covid-19". Edukasi melalui RRI Kendari ini dilakukan untuk lebih memudahkan Edukasi Kepada masyarakat secara luas. 


\section{Pembuatan dan Pemasangan Poster 6 langkah cuci tangan dalam Pencegahan Covid-19}

Pemasangan Poster mengenai 6 langkah cuci tangan yang baik dan benar di Kecamatan Kadia, Kecamatan Kendari, Kecamatan Kendari Barat dan Kecamatan Nambo.

\section{Pembuatan Video Edukasi 6 Langkah Cuci Tangan dalam Pencegahan Covid-19}

Pembuatan video edukasi yang berisi 6 langkah cuci tangan yang akan disebar ke media sosial agar masyarakat dan keluarga dapat melihat langkahlangkah pencegahan Covid-19 di masa new normal.

\section{Pembuatan Poster dan Video Penggunan Masker yang Baik dan Benar}

Pembuatan poster edukasi mengenai "Bagaimana Memakai Masker Kain dengan Tepat" dan pembuatan video edukasi yang berisi tentang "Penggunan Masker yang Baik dan Benar". Poster dipublikasi melalui Akun Instagram dan Whatsapp Group Edukasi Kec.Kendari, Kendari Barat dan Nambo. Sedangkan Video edukasi dipublikasi melalui Akun Youtube dan Whatsapp Group Edukasi Kec.Kendari, Kendari Barat dan Nambo. Pemasangan Poster Bagaimana Memakai Masker Kain dengan Tepat dilakukan agar saat masyarakat keluar rumah tetap dapat melakukan pencegahan penularan Covid-19.

\section{Penutup}

Kegiatan Pengabdian kepada masyarakat dalam rangka peran civitas perguruan tinggi dalam upaya tanggap bencana nasional melalui edukasi dan pencegahan penyebaran wabah pada masa pandemi Covid 19 di Kota Kendari dapat meningkatkan pengetahuan dan pemahaman serta kesadaran masyarakat terhadap upaya pencegahan covid 19 pada masyarakatdi Kecamatan Kendari, Kecamatan Kendari 
Barat, Kecamatan Kadia dan KecamatanNambo; Terdistribusinya masker APD, hand sanitizer, dan wadah cuci tangan sebagai upaya pencegahan transmisi Covid 19 di masyarakat serta terbantunya pengembangan UMKM yang terdampak covid 19 dengan melalui program pembuatan masker APD di Kecamatan Kendari, Kecamatan Kendari Barat, Kecamatan Kadia dan Kecamatan Nambo.

\section{E. Ucapan Terima Kasih}

Kami selaku tim pengabdian kepada masyarakat mengucapkan terima kasih kepada Bapak Rektor Universitas Halu Oleo (UHO) melalui Lembaga Penelitian dan Pengabdian kepada Masyarakat (LPPM) yang telah memfasilitasi biaya pelaksanaan melalui Dana DIPA Universitas Halu Oleo Nomor: SP DIPA-023.17.2.677510/2020.

\section{Daftar Pustaka}

Kementrian Pendidikan dan Kebudayaan. 2020. Diakses tanggal 1 september 2020 dari : https://www.kemdikbud.go.id/main/blog/2020/03/infografis-cegah-covid19-disatuan-pendidikan

Rothan HA, Byrareddy SN. The epidemiology and pathogenesis of coronavirus disease (COVID-19) outbreak. J Autoimmun. 2020; published online March 3. DOI: 10.1016/j.jaut.2020.102433.

Satuan Tugas Penanganan Covid 19. 2020. Diakses tanggl 8 september 2020 dari : https://covid19.go.id.

Susilo, A. et al. (2020) 'Coronavirus Disease 2019: Tinjauan Literatur Terkini Coronavirus Disease 2019: Review of Current Literatures', Jurnal Penyakit Dalam Indonesia, 7(1), pp. 45-67.

World Health Organization. Situation Report - 10 [Internet]. 2020 . Diakses tanggal 1 September 2020 dari : https://www.who.int/docs/default-source/ coronaviruse/situation-reports/20200130-sitrep-10-ncov. pdf?sfvrsn=d0b2e480_2 
World Health Organization. Naming the coronavirus disease (COVID-19) and the virus that causes it [Internet]. Geneva: World Health Organization; 2020, Diakses tanggal 2 September 2020 dari https://www.who.int/emergencies/diseases/novel-coronavirus-2019/technicalguidance/naming-the-coronavirus-disease-(covid-2019)-and-the-virus-thatcauses-it.

World Health Organization. Coronavirus disease 2019 (COVID-19) Situation Report - 70 [Internet]. WHO; 2020. Diakses tanggal 1 September 2020 dari : https://www.who.int/docs/default-source/coronaviruse/situationreports/20200330- sitrep-70-covid-19.pdf?sfvrsn=7e0fe3f8_2

World Health Organization. WHO Director-General's opening remarks at the media briefing on COVID-19 - 11 March 2020 [Internet]. 2020. Diakses tanggal 2 September 2020 dari : https://www.who.int/dg/speeches/detail/who-directorgeneral-s-opening-remarks-at-the-media-briefing-on-covid-19---11- march2020.

Wu Z, McGoogan JM. Characteristics of and Important Lessons From the Coronavirus Disease 2019 (COVID-19) Outbreak in China: Summary of a Report of 72314 Cases From the Chinese Center for Disease Control and Prevention. JAMA. 2020. 